\title{
LAS ONGs Y SU PAPEL EN EL FUTURO DE LA SOCIEDAD
}

\section{ANTONIO GUTIÉRREZ RESA}

Profesor titular de Servicios Sociales.

Universidad de Zaragoza.

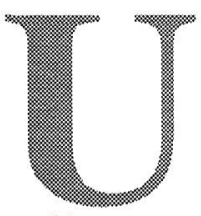

$\mathrm{n}$ «chequeo» al Estado de Bienestar exige tomar nota (1) de lo que fueron el conjunto de entidades sociales, sobre todo benéficas y sin ánimo de lucro.

En una aproximación histórica al Estado de Bienestar, comprobamos que cíclicamente se pasa del entusiasmo por lo público al interés por lo privado. (2) La utopía de lo privado hoy, ni siquiera alcanza al nuevo referente que buscan las ONGs en la consumada crisis del Estado de Bienestar.

Hoy (3) los cambios sociales provocan problemas complejos. Y no es aconsejable la sectorialización cuando hemos de actuar en drogas, inmigrantes y SIDA, por poner algunos ejemplos. Es necesaria la colaboración o participación de todas aquellas entidades no lucrativas y de carácter social y humanitario.

Estamos en condiciones de superar el egoísmo individual por el «egoísmo maduro». Preferimos hablar de (4) la solidaridad calculada como expresión, en parte, de las ONGs. Manifestación no sólo de igualdad, sino también del nuevo estilo que parece adivinarse en el futuro de la sociedad.

No es fácil vislumbrar el porvenir. No obstante, (5) las redes de solidaridad primaria o la solidaridad calculada, como redes de intervención, han de estar intercomunicadas y apoyadas por equipos técnicos, según la especificidad de las funciones y problemas de que se ocupen. Flexibilidad desde lo público y crecimiento compartido de la nueva responsabilidad civil (ONGs), es lo que apuntamos para los años venideros.

Resulta poco menos que imposible para la sociedad moderna institucionalizar todos aquellos procesos, que no hace tantos años cubrían la familia, los amigos y los vecinos. Es el caso de la ayuda a domicilio $^{1}$, de la soledad de mayores y jóvenes, de los procesos de

La ayuda a domicilio la requieren prioritariamente: personas de edad avanzada, de escasos ingresos, que viven solos y que presentan precaria salud y escasa autonomía. La ayuda 
duelo, o de la integración familiar, etc ${ }^{2}$.

El coste económico crece linealmente si aumenta el número de nuestros mayores, y queremos institucionalizar y tratar con sólo profesionales, cada uno de los procesos que requieren, diseñando la más absoluta pasividad de los beneficiarios.

Lo que se discute no es sólo un problema económico. También lo es de solidaridad, de libertad y de participación. Ahora bien, y antaño, ¿qué pasaba?. ¿No existían organizaciones no gubernamentales de carácter social?. Claro que sí. Sin embargo, el contexto era diferente. Es la clave para ir entendiendo el papel que cumplieron las ONGs, el que han cumplido, y el que debemos permitir que desempeñen en la futura sociedad, más allá de cualquier problema puntual.

Sin referentes o contextos es difícil orientarse. Es la razón de que hoy nos preguntemos $i$ Se puede entender el mundo social en que vivimos?, y el que está por venir ¿se puede adivinar?. Nos vamos a referir preferentemente a nuestro país, sin olvidar lo que sucede a nuestro alrededor.

1. El contexto principal es el Estado de Bienestar, ahora en crisis, y democrático. Es el referente europeo el que acabamos de plantear. En España hemos de hacer matizaciones, porque hasta el año 1975 no existía un régimen democrático, ni la cobertura social había respondido a los criterios europeos. Precisamente, las ONGs más importantes, como Cáritas Española, Cruz Roja y la ONCE, complementaban buena parte de la responsabilidad pública en materia de acción social y servicios sociales. Quiere decirse que el marco aconsejable de las ONGs con interés social y sin ánimo de lucro, junto a otras más, es la democracia, ya desde mediados del siglo pasado (1869). Con el régimen franquista, las mencionadas ONGs padecen algunas dificultades, a excepción de las que pertenecen a la Iglesia, y cuya muestra más significativa es Cáritas Española, que agrupa confederadamente a un buen número de las mismas. Sin embargo, la Acción Católica, que da origen desde el Secretariado Nacional de Caridad a Cáritas Española, tendría serias dificultades en torno a los años 60 . Una y otra representaban dos planteamientos de la Iglesia desde el siglo XIX: el interés por el mundo de los trabajadores y la preocupación por el ejercicio de la caridad cristiana. La lógica evolución de estas dos entidades se trastoca por la

mayoritariamente la prestan los familiares, siendo escasa la presencia del voluntariado. No es que la ayuda a domicilio la requieran sólo los pobres. Recordemos, no obstante, el servicio doméstico pagado como fórmula ya clásica para quien disponía de medios.

2 El 93\% de las mujeres españolas, según un estudio de la Unión Cívica Nacional de Consumidores y Amas de Casa de España, solicita ayudas del Estado para poder realizar mejor la labor de cuidar a sus parientes ancianos. Así lo titula el diario Heraldo de Aragón, 5 de julio de 1993: «Las amas de casa quieren recibir ayudas por el cuidado de los ancianos». 
Guerra Civil y la posterior dictadura. En ausencia de sindicatos libres y de estructurados servicios de Bienestar Social, democráticamente pactados, las citadas entidades se abren camino, gracias a los fines religiosos que persiguen prioritariamente. Sin embargo, se echa en falta una sociedad civil organizada en torno a los problemas sociales, mientras el naciente mercado trataba de acomodarse al incipiente bienestar consumista de nuestro país.

Ahora bien, transcurridos los años de la postguerra, ¿qué radiografía tenemos de España en torno a los años 60 y cómo se interpreta desde las ONGs?. Cáritas Española, por encargo de la Comisión Episcopal de Caridad y Asistencia Social de la Iglesia (1961), realiza el primer estudio sociológico sobre España, donde refleja la necesidad de la acción social comunitaria ${ }^{3}$, que ha de superar el asistencialismo que había venido practicando con ocasión de la Ayuda Social Americana (ASA). El primer estudio sociológico sobre nuestro país (Plan CCB) constituye una visión novedosa que critica el primer Plan de Desarrollo y el crecimiento no integrado del mismo, porque ignora los aspectos sociales. Era necesario contemplar la industrialización, las migraciones interiores, el turismo o los transportes.

Sin embargo, el progreso hacia el ámbito promocional y comunitario, en materia de acción social, no significaba abandonar la beneficencia y el asistencialismo ${ }^{4}$. Las necesidades de la época lo exigían y las ONGs, como Cáritas, habían de coordinar lo promocional y comunitario con las técnicas de la eficacia de la caridad.

Si el objetivo a perseguir consistía en conseguir una comunicación de bienes, «de modo que los que poseen bienes se solidaricen con los necesitados, poniendo a disposición unas ayudas y servicios asistenciales y sociales suficientes...», uno de los objetivos instrumentales $\left(6^{\circ}\right)$ del Plan consiste en la "promoción por parte del sector público de unas condiciones jurídicas, sociales y políticas favorables a la multiplicación y fortalecimiento de las organizaciones voluntarias dedicadas a la asistencia y promoción social, así como de

3 Acción comunitaria que apenas si tiene que ver con la democracia participativa proclamada en otros países por las mismas fechas, y que se asentaba en el derecho a tomar parte en las decisiones que afectaban a la vida comunitaria.

4 En España, y en la década de los sesenta, se piensa en la vigencia de tres conceptos: la caridad, la beneficencia y la asistencia social. «La caridad como elemento indispensable para humanizar la actividad de los servicios públicos; la Beneficencia privada como sistema de articulación idóneo de la generosidad de los particulares y como vía de subsidiariedad para permitir el acercamiento de los servicios a los necesitados; y la Asistencia social como superación de la Beneficencia Públicas. Cfr. Problemas fundamentales de beneficencia y asistencia social, 1967, Ministerio de la Gobernación, Colección Estudios, n. 10 ., Madrid. p. 272 
una creciente participación de la iniciativa pública en la financiación de las realizaciones asistenciales y sociales de dichas organizaciones, procurando para ello, además, el acceso de las mismas a las ayudas, subvenciones y créditos por ella arbitrados, en condiciones de igualdad real de oportunidades $»^{5}$.

No se podía olvidar que, junto a las necesidades nuevas, existían tres millones de españoles subalimentados ${ }^{6}$. Es la razón de que existieran 4.427 fundaciones benéficas y 1.435 de los pobres en 1963, y de que Cáritas distribuyera, con la colaboración de 2.894 parroquias, la Ayuda Social Americana, que ascendía a 2.051 .000 millones y alcanzaba a más de dos millones de personas?

Junto a Cáritas Española, otras instituciones dedicaban recursos financieros a fines benéfico-asistenciales. Es el caso de las Cámaras de la Propiedad Privada (con 8 millones de pesetas), de las Cámaras de Comercio (10 millones) o de la Asociación Española contra el Cáncer (31 millones) ${ }^{8}$, Cajas de Ahorro Benéficas (488 millones) 9 . Tampoco hemos de olvidar, ensanchando algo más el marco que nos hemos propuesto, al Frente de Juventudes, Sección Femenina o las Organizaciones de Apostolado.

El caso de Cruz Roja ${ }^{10}$, como entidad subsidiaria de ayuda pública, interviene, por aquella época, en menesteres asistenciales: hospitales policlínicas, auxilio en carretera, ambulancias, banco de sangre, enfermeras y veladores a domicilio, escuelas de enfermeras y auxiliares de clínicas, departamentos de chicas canguro, etc. ¿Se trata de una espe-

5 Cáritas Española (1965), Plan CCB, Ed. Euramérica, Madrid. p.16. El Plan CCB ensayaría cuatro planes sociales locales: Plan social Baza, en Granada; Plan Social en Lorca, Murcia; Plan socioeconómico de La Cabrera, León, y Plan social para los damnificados por las innundaciones de Granada.

6 Demetrio Casado, (1990). Sobre la pobreza en España, 1965-1990, Ed. Hacer, Barcelona. p.43. Cfr. del mismo autor (1976). La pobreza en la estructura social de España, Ed. Ayuso 1976, especialmente p. 46-47.

7 Cáritas en el año 1963 llega a recaudar 141 millones de pesetas. También se contaba con otras ayudas exteriores como Misereor (Obra Catùlica de los obispos alemanes), Cáritas Internationalis (Comisión de Secours d'urgence) y el Comité Internacional de Auxilio a la Infancia.

8 Ibid. Nota 3. p. 418. En 1973 la Asociación Española Contra el Cáncer recauda más de 314 millones de pesetas. Se trata de una corporación civil que nace en 1953, inspirada en los Estados Unidos y que persigue «promover la misión humanitaria y benéfica de la lucha contra el cáncer, mediante el desarrollo de funciones y actividades divulgadoras, preventivas, médicas y asistenciales».

9 Nos referimos a las inversiones del año 1963. En el año 1960 habían sido 227; en el 61, 271 millones y en el año 1962 con una estimación de 338 millones. Plan CCB Op. Cit. p. 395.

10 Nos referimos a la Cruz Roja Española aprobada por orden de la Junta Técnica del Estado el 13 de diciembre de 1936. 
cie de segunda Seguridad Social?. Lo cierto es que Cruz Roja, aunque parte de planteamientos que no contemplan el ánimo de lucro, también se autofinanciaba con parte de los servicios mencionados. Sin embargo, eran totalmente gratuitos: la Unidad de voluntarios (salvamento y socorrismo), Cruz Roja del Mar y Cruz Roja de la Juventud (boy-scouts).

Los medios económicos de que disponía Cruz Roja provienen tanto de las donaciones y edificios, cuyo patrimonio alcanza los $2.500 \mathrm{mi}$ llones de pesetas, como del Día de la Banderita, de las cuotas de los asociados y simpatizantes y de los cobros por los servicios prestados, que suman 1.203 millones en 1973. De semejante cantidad, 69,2 millones se dedican a la acción social en sentido amplio (socorrismo, voluntariado, juventud, Cruz Roja del Mar y socorro y emergencia) y 23,3 millones a la acción social propiamente dicha (asistencia social, prevención de drogas y alcohol, residencias de ancianos, guarderías infantiles y minusválidos ${ }^{11}$.

La conocida ONCE (Organización Nacional de Ciegos), como «beneficencia estatalizada» y entidad de derecho público, intenta resolver los problemas de los ciegos ${ }^{12}$. Ciegos, cuyo número asciende a 30.000 en 1974-75 (el 99\% de los invidentes españoles).

El único medio de financiarse la ONCE consiste en el llamado cupón pro-ciegos. A partir del cupón es posible financiar los programas dirigidos a sus afiliados. En el año 1972, del total de gastos (7.353 millones de pesetas) $1.154(68,16 \%)$ se destinan a la acción social y, en 1975, de los 12.015 millones, $2.026(69,52 \%)$ se invierten en acción social $^{13}$. Los gastos en acción social suponen los correspondientes a la Caja de Previsión, acción social, educativa, formación profesional y rehabilitación.

En línea con esa compleja franja de beneficencia-asistencia público-privada nos referimos ahora desde el ámbito gubernamental al $\mathrm{Pa}$ tronato de Apuestas Mutuas Deportivo Benéficas ${ }^{14}$. Patronato que más

11 Son datos contrastados en Luis Ibáñez y Ricardo Pellejá, (1975), Los Benefactores, Ed. Plaza y Janés, Barcelona. p.58-59 y en Gregorio Rodríguez Cabrero, «Reflexiones en torno a la dimensión económica del sector no lucrativo en España, en VV.AA. Las entidades no lucrativas de carácter social y humanitario», Ed. La Ley, Colección Solidaridad, n. ${ }^{\circ}$. Fundación ONCE, Madrid. p.326-327.

12 Aunque desde 1902 la Administración ya actúa en favor de los ciegos es el 13 de diciembre de 1938 cuando legalmente se puede hablar de la ONCE.

13 Cfr. Gregorio Rodríguez Cabrero, Op. Cit. p.329-331. Al mismo tiempo es curioso comprobar que las dificultades que encuentran Luis Ibáñez y Ricardo Pellejá en el Ministerio de la Gobernación para conocer lo recaudado por la ONCE lo suplen, coincidiendo con Rodríguez Cabrero, del siguiente modo: «Según nuestros informadores en la ONCE se recauda anualmente de 10 a 12 millones de pesetas». Millones que se distribuyen en premios y comisión de vendedores fundamentalmente.

14 El Patronato se establece por Decreto-Ley de 12 de abril de 1946. 
bien recauda e inmediatamente reparte las cantidades en premios, entre las siguientes instituciones: Diputaciones, Beneficencia, la Delegación Nacional de Deportes y la Junta Nacional Española de Educación Física. A partir de ese momento es responsabilidad de los organismos citados la gestión del dinero recibido. De los más de nueve millones que se recaudan en la primera temporada de 1946-47, se destinan a beneficencia 4.334.404,50. En 1962-63, de los 1.924.548,072 se destinan a beneficencia $30.945 .304,04^{15}$.

El periplo español de las entidades u organizaciones no gubernamentales podría cerrarse haciendo mención de ANIC (Asociación Nacional de Inválidos Civiles), la Federación Española de Asociaciones Protectoras de Subnormales, y la Asociación de Amigos de UNICEF.

ANIC $^{16}$ trata de proteger a sus asociados (86.224 en 1974) en el campo médico, formativo, laboral, socio-cultural y asistencial. Se financian con las cuotas de los afiliados y las subvenciones. El segundo apartado constituye la partida importante y un capítulo más de la «beneficencia nacional» proveniente de diversos ministerios. La acción asistencial es la prioritaria y se destina a prótesis o atenciones pedagógicas, por poner dos ejemplos.

La Federación Española de Asociaciones Protectoras de Subnormales es una entidad benéfica más de la época (1964) con 20 asociaciones. En el año 1970 era declarada institución de utilidad pública y en 1974 eran 107 las asociaciones que integraban la Federación. El objetivo era bien claro: la aceptación o integración de los subnormales en la sociedad. Para lo cual las acciones, que fundamentalmente desempeñan las asociaciones locales y provinciales, irán en la línea mentalizadora por un lado, y de presión al Estado por otra. Pero, de modo más concreto, podemos decir que disponen de centros de trabajo y de residencias y colegios.

Sus recursos económicos provienen de su patrimonio, cuotas, aportaciones de los miembros que colaboran, subvenciones, donaciones, etc., llegando a alcanzar en 1971 la cantidad de 1.500 .000 pesetas, y en 1974 es de 5.667.000.

Finalmente, nos vamos a referir a la Asociación de amigos de UNICEF, institución que surge a comienzos de la década de los cincuenta y como Fondo para la Infancia dentro de las Naciones Unidas. Pronto contaría en España y en Barcelona (1956) con la primera Asociación de Amigos de UNICEF. Posteriormente (1974-75), se contabilizan 18 instituciones de Amigos de UNICEF.

16 El Real Decreto-Ley que le da vida jurídica aparece en el BOE el 22 de diciembre de 1958. 
Se nutre de las contribuciones de los gobiernos, de donaciones, operación «Tarjetas» y otros, persiguiendo como fines la captación de fondos y la organización de actividades culturales. En el año 1974 se alcanzan los 52 millones de pesetas.

El breve repaso del asociacionismo benéfico de nuestro país rendía al filo de estrenar la democracia en España la cifra de 30.000 millones en el último balance. Claro que «poco más de la mitad de este dinero fue manejado por un sólo organismo: el Patronato de Apuestas Mutuas Deportivo Benéficas, precisamente el único que no juega a la beneficencia ${ }^{17}$ y que no puede considerarse como ONG. Sin embargo, si tenemos en cuenta que las partidas de la Seguridad Social ascendían a 300.000 millones y los del Ministerio de Educación y Ciencia a 100.000 en el año $1975 \ldots$... ¿qué se podía esperar que cambiara la beneficencia?.

Hemos presentado algunas de las principales ONGs que antes de 1975 practican la beneficiencia sin que el Estado asumiera la cobertura social exigible. El contexto no democrático permite comprender sus objetivos y toda una serie de festivales y tómbolas benéficas, de tanta tradición en España.

2. En 1975 se instaura la democracia en España y el pujante movimiento civil comienza a tomar importancia. Las asociaciones civiles, como asociaciones de barrio fundamentalmente, que de modo clandestino comienzan a gestarse desde el año 1971 hasta 1974, se expanden tras la democracia (1977), participando junto a las ONGs de un espacio socio-político que abre nuevas expectativas tanto entre los movimientos sociales como entre las Organizaciones no Gubernamentales ${ }^{18}$. En otros países, serán los movimientos estudiantiles, pacifistas, feministas y ambientalistas los que por las mismas fechas se constituyen como «nuevos movimientos sociales» ${ }^{19}$.

Comenzaba a producirse una cierto entusiasmo por lo público y por la sociedad civil en un país que estrenaba la democracia y que, al mismo tiempo, comenzaba a sentir los efectos de la crisis económica. Entre tanto, se intentaba organizar un «Estado de Bienestar» que cumpliera con las esperanzas depositadas de que lo público iba a solucionar los problemas básicos de cobertura social de nuestro país. La restauración democrática abría la esperanza de múltiples proyectos.

Aquel primer entusiasmo alcanzaba su máxima altura en 1982 con la subida al poder de los socialistas, tras un período de transición de-

17 Luis Ibáñez y Ricardo Pellejá, Op. Cit. p. 179

18 Alain Touraine, (1990) Movimientos sociales de hoy, Ed. Hacer. Barcelona. p.153-160. Las asociaciones surgen en los barrios de las ciudades españolas por problemas puntuales que afectan a los barrios, y que impiden mejorar la calidad de vida de los ciudadanos.

19 Russell J. Dalton y Manfred Kuechler, (1992), Los nuevos movimientos sociales, Ed. Alfons el Magnànim, Generalitat Valenciana, Valencia. p.19-42 
mocrática, y comenzaba a decrecer inmediatamente. De 1982 a 1993 hemos tenido ocasión de comprobar lo que ha dado de si el nuevo contexto. Hoy el tópico es hablar del «desencanto de lo público».

Sin embargo, aunque en la actualidad se acentúa el desencanto de lo público, nadie duda de que el Estado habrá de seguir interviniendo en la promoción del bienestar de los más desfavorecidos para alcanzar la universalización de los derechos sociales de todos los ciudadanos.

El Estado de las Autonomías interviene en este período para lograr no sólo la descentración sino la descentralización y más eficaz operatividad de los recursos.

También la sociedad del bienestar y el mercado han presionado tanto sobre las necesidades, que buena parte de ciudadanos se ven relegados de satisfacerlas en los circuitos normalizados de la sociedad. La complejidad social hace aparecer, de esta manera, nuevas manifestaciones de necesidad que ONGs y nuevos movimientos sociales son los únicos capaces de satisfacer.

Sin embargo, la competividad también alcanza a la sociedad civil, que se reagrupa en torno a organizaciones, entidades o movimientos de fuerza, que acumulan redes sociales de muy variado signo. Lo mismo ocurre entre las ONGs sin ánimo de lucro y el voluntariado social como sector que nos interesa.

¿Qué ocurre?, ¿van a desaparecer las ONGs?, ¿les van a faltar clientes?, ¿Puede deteriorarse la imagen y poder de semejantes entidades?, ¿sirven para algo?. Lejos de escandalizarnos por tales interrogantes, entendemos el esfuerzo que hacen por demostrar eficacia, innovación, flexibilidad y creatividad en los métodos, y profundización en el conocimiento de los problemas y las necesidades humanas. Es la cultura de la eficacia, de la eficiencia y racionalidad, aplicada a la acción social, lo que asumen prestado del ámbito del mercado. ¿Nueva ideología entonces?. No, se trata de responder a los nuevos retos de rentabilidad y justificación social que exige cualquier programa serio de acción social, al igual que la rentabilidad económica exigible a la inversión en bolsa. Es decir, se quiere que la acción social no gubernamental se asemeje en lo eficaz y competitivo al mercado y a lo privado, mientras en la responsabilidad de cobertura y universalidad se identifica con el ámbito público y del Estado.

No obstante, la fecha de 1975, marcaba para las ONGs más conocidas, el inicio de un período que se afrontaba con cierta inquietud. Cáritas Española, por ejemplo, se lo había planteado con anterioridad. Exactamente en el período en que es presidente de la misma D. Francisco González de Posada (1973-1976). Es la «Etapa de denuncia profética o de crítica». Le sucederá como presidente D. José María de Prada (1976- 
1979). Una etapa que hemos denominado de «profundización» ${ }^{20}$. Se asume la denuncia de la situaciones injustas y se cree superado el asistencialismo abogando por la promoción, aunque deba ejercerse la asistencia. Además, Cáritas es consciente de que forma parte de una sociedad civil difícilmente sustituible por el Estado. La «caridad política» será el reto de Cáritas frente a una sociedad democrática de la que desconfía que logre la igualdad. Es la razón de propugnar la justicia en la caridad cristiana, para defender a los más necesitados ${ }^{21}$.

El paso de los años, desde el inicio de la democracia en nuestro país, no han hecho de Cáritas, ante la permanencia de ciertas necesidades, una empresa de servicios. La institución, sin cambiar sus estatutos, busca un marco más amplio, que es Europa, para coordinar y superar las necesidades, mediante programas inter-europeos que ponen a prueba la eficacia de la acción caritativa, la coordinación y la investigación.

Cruz Roja entra en la democracia con los esquemas del pasado, aunque los años posteriores flexibilizarán sus estructuras, sus programas y sus conexiones con la sociedad civil. Sin embargo, existen dificultades de orden jurídico, como el vigente Real Decreto 690/1978 de 27 de marzo, de ordenación de la Cruz Roja Española, cerrando la posibilidad a cualquier reforma democratizadora. También estaban vigentes los Estatutos de la Institución, aprobados por Orden de la Junta Técnica del Estado, de 13 de diciembre de 1936. Será el Ministerio de Trabajo y Seguridad Social y la Dirección General de Acción Social quienes posibilitan la aparición del Real Decreto 1474/1987 de 27 de noviembre, y los Estatutos de la Institución, aprobados en Consejo de Ministros de 22 de abril de 1988.

Los nuevos objetivos de Cruz Roja ${ }^{22}$ perseguirán el bienestar social mediante «la promoción y ejecución de programas de servicios sociales especialmente para el desarrollo de actividades de prevención, de asistencia y de inserción social», entendiendo que son actividades solidarias y «complementarias de las llevadas a cabo por los sistemas públicos de bienestar social y de calidad de vida».

En 1989 se realizan las primeras elecciones democráticas en Cruz Roja, consolidándose el proceso de renovación anterior. A partir de 1990 , la institución, sabedora de sus propias limitaciones ${ }^{23}$, proyecta

20 Antonio Gutiérrez Resa, «Estudio Informe sobre Cáritas española», en Organizaciones Voluntarias en España, Ed. Hacer, Barcelona, 1992. p. 295

21 Así es como se llega a la Asamblea del Episcopado de 1981 en la que los obispos presentan a Cáritas para que sea «la vanguardia por encima de otras prioridades».

22 La Cruz Roja se define hoy como una Institución Humanitaria de carácter voluntario y de interés público.

23. Limitaciones que hacen reflexionar sobre la limitada acción en la base y la excesiva dependencia de los programas de la administración, aunque también se cuenta con un incremento de la solidaridad social y una imagen de confianza. 
un Plan dirigido a los más desprotegidos: personas mayores, sectores marginados y los más desfavorecidos del tercer mundo. Para lo cual propiciará la participación en una consolidada y bien coordinada organización institucional.

Cruz Roja y Cáritas Española invertirán en sus programas de acción social en torno a los diez mil millones de pesetas (1990). La ONCE gastará en acción social (1987) un total de 42.416 millones de pesetas, y las Cajas de Ahorro 26.780,0 millones (1987).

La ONCE, al igual que Cruz Roja, tardará en desarrollar el proceso de adaptación al nuevo marco democrático. Es lo que sucede con el Real Decreto 1.041/81 de 22 de mayo, y con el Real Decreto 2.385/85 de 27 de diciembre, que modifican la estructura orgánica de la ONCE. Así es como tienen lugar las primeras elecciones democráticas en enero de 1982 y la constitución de su primer Consejo General. Se trata de un importante período en la ONCE (1982-1986) que modifica interna y externamente a la institución, y que continuaría en abril de 1986 con la celebración de las segundas elecciones democráticas.

En 1988, y por Orden Ministerial de 2 de agosto, se configura LA FUNDACIÓN ONCE como Fundación de Beneficencia Particular, como culminación del proceso de solidaridad de la ONCE con otros colectivos de minusválidos. La ONCE es la única fuente de financiación, con el 3/100 anual de la venta del cupón, lo que supone, aproximadamente, la cantidad 7.500 millones de pesetas en el año 1979.

El fin primordial de la ONCE consiste en lograr «la autonomía personal plena e integrada de los ciegos en la sociedad». En la misma línea se manifiestan los fines que han de cumplir los programas de la Fundación: integración social, prevención de la minusvalía, rehabilitación, educación, formación profesional, empleo, supresión de barreras arquitectónicas y prestaciones para personas minusválidas.

De entre las ONGs más conocidas, las tres mencionadas han desarrollado sus estrategias de adaptación no sólo dentro del sistema democrático, sino también en el nuevo período de «desencanto», postmoderno, pragmático y egoísta. Son tres entidades, consistentemente organizadas, y con dilatada experiencia y tradición. Luchan por mantenerse institucionalmente como tales, por justificarse, mediante la acción social, y por conectar con la sociedad, nutriéndose de una base social organizada.

Otras ONGs han ido surgiendo, desde los años 1975, al socaire de la democracia y de heterogéneos movimientos sociales. ¿Por qué han ido apareciendo?. Porque no se han cumplido las expectativas creadas por el ámbito de lo público..., podría ser si tenemos en cuenta los espacios sociales que se abren a la participación. Hoy, sin embargo, se retorna a posiciones críticas, corporativas, consumistas, no quedando otra 
salida que la solidaridad social ante la falta de compromiso público ${ }^{24}$. Una muestra de lo que decimos es el avance cuantitativo y cualitativo del conjunto de voluntarios. Los podemos identificar en las entidades de acción social mencionadas y también en asociaciones menos formalizadas hasta llegar a las redes de comunicación, con escasos medios, pero de gran flexibilidad, eficacia, y contenido ético. Es una alternativa en el conjunto de las ONGs, de las asociaciones, y de la sociedad civil, para satisfacer necesidades que habían alcanzado cierto grado de profesionalización y corporativismo, por no decir de institucionalización y control en el modo de satisfacerlas. Las ONGs con voluntarios y sin ellos 25 , la mayor o menor formalización de los mismos y la sociedad civil como conjunto, tienen la palabra sobre el futuro que pueden correr los problemas de la acción social. La cooperación solidaria es la base para intentar suplir la falta de compromiso social, la falta de sensibilidad por los problemas y desconexión de la naturaleza social, con que se delata el Estado moderno.

Hablamos siempre con referencia a la acción social y los servicios sociales. Incluimos en el conjunto a ONGs, voluntarios, asociaciones y cualquier sistema de comunicación más o menos flexible y formalizado. Aunque, en rigor, no es lo mismo una asociación que un movimiento social, ONGs con voluntarios que una Plataforma del Voluntariado, una entidad benéfica y una ONG sin ánimo de lucro, presumimos que las une, porque existe, un sistema de comunicación y acción que les permite renovarse y afrontar adaptativamente los problemas sociales, y sobre todo los problemas locales. En 1990 están calculadas en 50.000 las ONGs en los países en desarrollo y que actúan en muy diversos campos como la acción social y los servicios sociales o la educación no convencional.

¿Se puede llegar a cuantificar el mundo asociativo?. «Llegamos a la sorprendente conclusión de que las asociaciones cuentan en nuestro

Luis Enrique Alonso, (1993), La reconstrucción de las señas de identidad de los nuevos movimientos sociales, Rev. Documentación Social, n. ${ }^{\circ} 90$. Cáritas, Madrid. p.14-22.

25. Las ONGs citadas con anterioridad, como Cáritas y Cruz Roja, tienen voluntarios y los forma la propia institución. Sin embargo, existen otras ONGs, como Médicos Sin Fronteras, cuya naturaleza institucional la definen exclusivamente los 900 voluntarios que actúan en 70 países del mundo. Cfr. VV.AA. (1993) Médicos Sin Fronteras. Poblaciones en peligro. Ed. Acento. Madrid.

Para ilustramos de las ONGs que últimamente han intervenido y siguen interviniendo en el ámbito internacional, bastaría echar un viztazo a la prensa diaria: Cfr. «Más rápidas, más eficaces. Las ONGs han tomado la delantera a los Gobiernos para paliar las catástrofes humanitarias», El País, 27 de julio de 1994. «Espaldarazo de la ONU en el Cairo a los Organizaciones No Gubernamentales», El País, 5 de septiembre de 1994. «Las ONG españolas se llevan el 10\% de la ayuda humanitaria de la UE», El País, 12 de junio de 1994. 
Estado, con al menos quince millones de afiliados ${ }^{26}{ }^{2}$. Ahora bien, con el ánimo de ser más precisos, son las organizaciones voluntarias, como ONGs y alternativa de cooperación solidaria, las que más interesan ${ }^{27}$.

No parece haber decrecido el número de asociaciones y su aportación a la sociedad, aunque es difícil cuantificarla. Lo que sí se supera es la dualidad público-privado, por cuotas de responsabilidad que asume la sociedad civil. La pronta adaptación a los cambios y transformaciones sociales considera obsoletos aquellos sistemas de cobertura social público-estatales e institucionalizados. «En la situación actual se trata fundamentalmente de asentar algo distinto en el lugar del Estado de Bienestar. Es bien sabido que el bienestar no se puede acrecentar sin límites de año en año. Advertir sobre los límites del crecimiento -esto ha dejado ya de ser el problema desde hace tiempo-. El impulso no lo constituye el crecimiento en sí, sino el deseo de compensaciones ${ }^{28}$.

Si hasta ahora el tópico de que nos hemos alimentado ha sido identificando lo público como lo estatal, y lo privado con el mercado, ahora hemos planteado la realidad de las ONGs para expresar la vía intermedia que intenta superar la dualidad de los contrarios, manteniendo la utopía, todavía posible, de ir más allá de los intereses de unos y otros. Queremos decir que las ONGs representan la superación del Estado y el mercado. Es la gente, el público, la que quiere intervenir, participar y ejercer la presión correctora suficiente, frente a las estructuras de poder que dominan al Estado y al mercado.

3. Es obvio que los cambios sociales han hecho de nuestro sistema social una realidad compleja. Si es así como sucede, no es fácil presentar soluciones simples, aunque se siga teorizando sobre sistemas de cobertura que adolecen de complejidad conceptual. No se puede seguir hablando, por ejemplo, de servicios sociales generales y específicos, con la intención de clasificar la oferta existente y aprehender la realidad social. Con tales expresiones, más bien parece que huimos o escapamos al compromiso de afrontar la complejidad de los problemas y de la misma sociedad ${ }^{29}$.

Si la realidad social se ha hecho más compleja, los problemas que surgen en su seno presentan un mayor número de conexiones o rela-

26 Tomás Alberich, (1993), La crisis de los movimientos sociales y el asociacionismo de los años noventa, Rev. Documentación Social, n. ${ }^{\circ}$ 90, Cáritas, Madrid. p.111-112.

27 Demetrio, Casado, (1992), Organizaciones voluntarias en España. Ed. Hacer, Barcelona.

28 Niklas Luhmann, (1993), Teoría política en el Estado de Bienestar, Alianza Editorial, Madrid. p.150-151.

29 No comprobamos que exista el sexto sistema de los servicios sociales, tal y como lo expresan Kahn y Kamerman. Existe un conjunto de servicios sociales, cuya complejidad habría de aumentar, para afrontar los problemas sociales de mayor actualidad: paro, inmigración, sida y drogas y personas mayores de 75 años. 
ciones, ofreciendo múltiples perspectivas de la presumible realidad identificable. Por ello mismo, es difícil decidir, priorizar, planificar. Si cambia el sistema de relaciones, de comunicación, se modifican las posibilidades y los mismos problemas. Queremos decir, siguiendo a $\mathrm{N}$. Luhmann, que ni la sociedad ni los problemas se pueden plantear con unos conceptos binarios que dejan escapar toda la multiplicidad factorial que los define. Los problemas no se van a resolver por plantear las soluciones en lo público o en lo privado frente a su contrario, o diciendo que el sector público ha llegado a ser demasiado grande. Los países menos industrializados han de aumentar los gastos para asegurar unos niveles de cobertura, mientras la Sociedad del Bienestar los está reduciendo sin haber alcanzado su universalidad.

Para N. Luhmann, complejidad significa «la existencia de un conjunto de posibilidades superior a las que de hecho pueden ser realizadas y exigen algún tipo de selección entre ellas». Se exige, claro está, la selección, y se ve necesario reducir la complejidad de los problemas, mientras el propio sistema funcional crece en complejidad. La sociedad no es homogénea, es plural, es diferente, exigiendo la intervención de entidades (ONGs) que fomenten el diálogo y la comunicación entre las diferencias. Diferencias que pueden provocar y provocan fuertes tensiones y reacciones como la xenofobia o la insolidaridad, ante la creciente complejidad social.

Hemos pasado de ser uniformes por ser fácilmente identificables, a ser sujetos plurales, más complejos, por tener que convivir con el «otro» en el mismo edificio o calle. Este es el motivo por el que nos planteamos dar razón de las ONGs ante la complejidad de los problemas, justificando una acción que, atenta a lo particular de lo que ocurre, es capaz al mismo tiempo de universalizar su acción, hasta donde sea posible, por medio de la comunicación y la coordinación.

El problema de la inmigración, por ejemplo, adquiere mayor complejidad en los últimos años porque el contexto o contextos en que aparece hacen de la inmigración un problema múltiple, un problema complejo. El gran contexto de la crisis del Estado del Bienestar, es el resultado de un proceso que se manifiesta entre las muchas complejidades que produce, en la citada inmigración. Existen bastantes más complejidades, como la drogadicción o el sida. Se trata de situaciones que colocan a la sociedad y a sus sistemas en situaciones cada vez más difíciles, que desbordan a la propia sociedad. Se puede caer en la tentación de penalizar, imponer, suprimir las diferencias. También se puede mantener la complejidad, sin anularla, decidiendo con rapidez y dispuestos siempre a admitir una renovación continua.

Llegar hasta los problemas que se padecen implica el apoyo a la autoayuda cuando existe, y organizarla cuando no se ha producido. No es que solucionen así los problemas. Se llegan a conocer las dificulta- 
des de las personas concretas, alcanzando una situación de partida que permite intentar la solución de los problemas. Naturalmente, que habrá que modificar los patrones con que trabajamos para actuar en las situaciones puntuales. Aproximarse al ámbito local, a las personas que padecen la desventaja social y a su complejo mundo, exige de la acción social algo más que mera política social. Exige, además de una amplia cobertura en política social y un conocimiento de los niveles de participación de que son capaces, una justificación del esfuerzo que nace de su propia capacidad de comunicación y un reconocimiento positivo por parte de la sociedad. Sólo de este modo la acción social supera los niveles de la ayuda puntual, avanzando en la modificación de las condiciones internas, de personalidad, o subjetivas que padecen quienes han quedado situados en el amplio marco de la marginación.

El Estado de Bienestar parece reconocer su impotencia a la hora de descender hasta los individuos, sus motivaciones y sus problemas. Es el momento de hacer mención de las ONGs, de los voluntarios y de cualquier movimiento social conectado con el nuevo modo de satisfacer las necesidades, incluso aquéllas que se definen como elementales. Ya no se trata de más dinero, ni más control burocrático. Se trata de posibilitar al máximo la interacción entre las personas, la flexibilidad, la descentralización y la efectiva participación, superando la dualidad de lo bueno/malo, verdadero/falso, por la responsabilidad civil que gravita sobre todos los ciudadanos para ser más autónomos y solidarios al mismo tiempo.

Es necesario, por tanto, un tipo de planificación a corto plazo. A largo plazo sería abarcar excesiva complejidad en detrimento de una acción social que necesita, cada vez más, resultados palpables y motivación suficiente para seguir actuando y reducir la inestabilidad. Es un modo de intentar atajar las consecuencias de la planificación a largo plazo del Estado de Bienestar. Siempre mayor bienestar para todos los ciudadanos, ha sido la cantinela. Sabemos que es imposible, cuando las múltiples crisis lo ponen de manifiesto. Es más, las ONGs no van a transformar la sociedad. Sin embargo, pueden ayudar a que las personas superen sus períodos de crisis, recobren parte de la dignidad perdida o aumenten su libertad de elegir.

El avance de la medicina moderna no ha impedido que aparezcan virus indomables, ni el desarrollo del sistema educativo el fracaso escolar, ni la mayor libertad y democracia un número de personas que no acaban de acomodarse y recurren a la droga. En éstos y otros problemas, las decisiones que toma la administración se quedan cortas, cuando no llegan tarde. Se necesita tanto de la burocracia como de los profesionales, voluntarios, ONGs y movimientos interesados en la acción social. No es fácil saber qué sistema combinatorio puede tener mayor éxito. En cualquier caso hay que intentarlo y rápidamente. 
Como ejemplo de problema complejo, que se propaga en nuestra ciudades, hemos citado el sida. Se calcula que en 1992 diez millones de seres humanos son portadores del VIH (virus de inmunodeficiencia humana). El contexto al que nos hemos referido es el de las grandes ciudades $^{30}$. Y en ellas el sistema sanitario ha de enfrentarse no sólo al número de enfermos, sino también al rápido aumento de los mismos, sean declarados o no ${ }^{31}$. El sistema científico también afronta su parcela de complejidad al no poder actuar, por no saber, sobre quienes desconocen ser portadores del virus. El mismo virus se muestra sumamente complejo y versátil en su comportamiento, siendo difícil su tratamiento. Y las tipificadas prácticas de riesgo se complementan ahora con aquellas otras que pueden albergar a hombres heterosexuales, mujeres, niños y profesionales de la medicina ${ }^{32}$.

Mostrar a la sociedad la verdad del sida es darle la posibilidad de que se utilice «para justificar la marginación y el rechazo de los afligidos por parte de los individuos sanos». Sin embargo, «tal rechazo estimula lazos de unión y rituales colectivos entre los miembros de las comunidades afectadas que les sirven de apoyo, de autoayuda y de defensa contra los ataques y la animosidad de la mayoría» ${ }^{33}$.

También interviene la economía formando parte de la complejidad del sida. Los tratamientos son muy costosos y puede llegarse a «controlar» el número razonable de quienes pueden ser atendidos sanitariamente.

Crece la complejidad del problema cuando, para prevenir, se ponen en práctica métodos, como el uso del preservativo, que ponen en tela de juicio valores tradicionales. También peligran las prácticas solidarias con países de los que nos llegan emigrantes, que, con toda probabilidad, concentran mayores posibilidades de propagación que otros, según los lugares de procedencia.

Se modifican las conductas sexuales y se amplían las redes de comunicación entre los problemas. Por ello mismo, hablar del sida es hablar también de ciertas prácticas sexuales y de drogas ${ }^{34}$.

Después de haber transcurrido 10 años de aquellas primeras muertes por sida en Sevilla, se impone idear soluciones urgentes. Solucio-

30 Luis Rojas Marcos, (1992), La ciudad y sus desafíos. Héroes y víctimas. Edit. Espasa Calpe. Madrid. p. 148-159.

31 En el año 1963 nos encontramos con que los casos de cáncer eran declarados confidencialmente. Exactamente fueron declarados 14.690 en toda España. La provincia de Zaragoza ocupaba el segundo lugar con 1.625 casos, según el Plan CCB. p. 80.

32 Cfr. Cruz Roja Española, (1992) Sida, Sociedad y Derechos Humanos, Madrid.

3. Luis Rojas Marcos, Op. Cit,. p. 152.

${ }^{34}$ Son los motivos por los que cualquier programa sobre el sida inciden tanto en la prevención. Cfr. Programa para la prevención y control del sida y la infección por el VIH en la Comunidad Autónoma de Aragón. Cuadernos de salud. 1. (1989). Diputación General de Aragón. Departamento de Sanidad, Bienestar Social y Trabajo. 
nes que «deben ser flexibles, con el fin de ir adaptando a las variaciones que la epidemia vaya presentando, tomarse con la urgencia que la situación requiere e ir encaminadas a asegurar la mayor calidad técnicas y humana para toda la población infectada por el $\mathrm{VIH} »^{35}$. Queremos destacar la necesaria colaboración con las ONGs, por ser «la única forma real de cubrir la gran mayoría de las necesidades psicosociales de los pacientes».

Hablamos de 150.000 enfermos en España que necesitan de los profesionales ${ }^{36}$ y de las ONGs no sólo para disponer de más medios económicos, sino sobre todo para compartir la soledad y marginación que padecen ${ }^{37}$. Más allá de la llamada «solidaridad del diseño» está la que apuntamos: la solidaridad que para convivir modifica nuestros principios de convivencia.

Sobre el complejo problema de la drogadicción, tan sólo apuntar la necesaria coordinación exigible desde el llamado tráfico de drogas hasta llegar al drogadicto que la consume, privado o no de libertad. Es la razón de que existan diversos sistemas sociales coimplicados: socioeducativos y preventivos, penales, asistenciales y de integración, por citar los fundamentales. No olvidamos las ONGs que intervienen, $\tan$ positivamente, en el problema de la drogadicción ${ }^{38}$. Una fructífera experiencia entre ONGs y Administración, a lo largo de varios años, con el Plan Nacional sobre Drogas, ha demostrado la posibilidad y necesaria cooperación de asumir responsabilidades conjuntamente ante problemas tan complejos como el de las drogodepedencias. Un claro ejemplo de responsabilidad civil que ha desarrollado la participación y el voluntariado. Desde el año1986 ${ }^{39}$ la sociedad española ha madurado, llegando a entender que la flexibilidad también es aplicable al mundo de las drogas, con el fin de adaptarse a las cambiantes circunstancias que presenta la sociedad en ese mundo de marginación y negocio, en-

35 Luis Buzón, (1993). «La asistencia», en La década del sida, El País. 11 de marzo. p.3. No queremos tampoco

36 Cfr. Informe dirigido a profesionales de la educación y sociosanitarios. El Sida y la infección por el VIH. (1993). Diputación General de Aragón. Programa sobre el sida. Dirección General de Salud Pública.

37 Queremos señalar que cuando los enfermos viven procesos irreversibles, es importante cuidar todos los aspectos psicológicos y el trato humano que requieren dichas personas. De este modo la muerte no ha de ser un fracaso profesional personal, sino un proceso que se asume para cuidar de su más alto nivel posible material y anémico.

38 Antonio Gutiérrez Resa (1992), La responsabilidad civil (asociacionismo) en drogodependencias. Rev. Servicios Sociales y Política Social. n. ${ }^{\circ}$ 24. Madrid. pp. 28-60. Cfr. VV.AA. (1989). Organizaciones voluntarias e intervención social. Estudio aplicado en el campo de las toxicomanías. Ed. Acebo, Madrid.

39 En el año 1986 (12 de diciembre) se celebraba la I Reunión Nacional sobre participación y movimiento asociativo en el tema de drogas. 
fermedad y delincuencia, penal y de integración, asistencial e integral.

El tercer problema que habíamos citado, como claro ejemplo de complejidad social, es la inmigración. Europa y España han recibido un elevado número de inmigrantes. ¿Motivos?. Aunque prioritariamente son económicos, también los hay que llegan por razones políticas e ideológicas.

Lo cierto es que atrás quedaron en España aquellos años 60; toda una época de emigrantes españoles que se dirigieron a centroeuropa. El cambio económico y político atrae ahora a nuestros vecinos del Magreb y latinoamericanos, entre otros.

Si el mayor aumento parece detectarse en 1989, actualmente hay más de 500.000 inmigrantes legales residiendo en España. Hablamos del 2,3\% del total de la población, sin hacer mención de aquellos otros que se consideran ilegales, pero que constituyen una innegable realidad. Basta ojear los periódicos nacionales o locales para leer de continuo titulares que comprometen a los inmigrantes, tanto en el campo como en las grandes ciudades ${ }^{40}$.

También Aragón sabe de inmigrantes. Los tiene en el campo y en la ciudad. Y sólo Zaragoza se estima que alberga 6.000 ó 7.000 inmigrantes, de los que el $28 \%$ son legales ${ }^{41}$.

¿Cuáles son los problemas que centran la complejidad de los inmigrantes?. Fundamentalmente tres: falta de trabajo, no tener vivienda y las diferencias culturales con el país en el que se encuentran. En torno a ellos giran toda una serie de variables que se producen en la legislación, en la economía sumergida, en los alquileres de pisos, en la no aceptación y marginación, en la sanidad, en el idioma, cultura e identidad y en las redes de información y ayuda. No obstante, conviene precisar, cuanto antes, que quienes más necesidades padecen son precisamente $\ll$ los ilegales» ${ }^{42}$.

Tan enorme complejidad requiere «soluciones» a corto y largo plazo, contando con que el $40 \%$ de los españoles tiene actitudes racistas, pero también con que existen asociaciones y movimientos solidarios ${ }^{43}$ capaces de aportar soluciones reales. También es necesario ampliar la

40 No es casualidad que el primer número de la revista de ciencias sociales, Sociedad y Utopía, de la Facultad de Ciencias Políticas y Sociología «León XIII» lo dediquen a: Inmigrantes en España.

41 Diario 16. Aragón. Zaragoza. 24 de mayo de 1993. p.8. Se trata de un resumen del estudio realizado por María Reyes Abril Esco y Virginia Moreno Lamana, sobre «Inmigración en Zaragoza». Trabajo no publicado.

42 En principio nos referimos a los inmigrantes que huyen, por motivos estrictamente económicos, de las condiciones de pobreza de sus países de origen. Pero caben no pocas puntualizaciones, como las que podrían referirse a los refugiados. Cfr. «Refugiados y ciudadanos», El País, 15 de Julio de 1993. Temas de nuestra época.

43 La Plataforma Ciudadana de Solidaridad en Zaragoza, alberga a 40 ONGs. 
escasa investigación existente sobre la situación de la población extranjera, para acortar la distancia existente entre lo que podamos decir y la realidad de los hechos ${ }^{44}$.

4. La probada complejidad de los problemas sociales nos anima en este cuarto punto a plantear la necesidad de superar el egoísmo individual por el egoísmo racional. De no tener en cuenta al prójimo, pasamos a considerarlo como imprescindible para nuestro reconocimiento y logro del bienestar personal. Y no sólo eso: la identidad grupal, la comunidad, el progreso requiere de la contribución de los demás.

Se parte de un diálogo, de una comunicación, que en principio reconoce la presencia del otro. Ahora bien, hemos de buscar y descubrir los móviles por los que merece la pena contactar, empatizar con los demás seres humanos. En principio, el ser humano ha descubierto y sentido que es contingente, que necesita de los demás. No es que constituya una novedad. Sin embargo, por haber alcanzado hoy tan altas cotas de complejidad social, se hace más evidente la dependencia entre los hombres y el ejercicio de la libertad y participación.

$\mathrm{Y}$ ante nosotros se muestra la llamada realidad social. Es cierto que existen claras diferencias entre los seres humanos. Y no sólo de diferencias cabe hablar, también se producen claras injusticias a la vuelta de la esquina y algo más lejos en cualquier parte del mundo.

Apelamos a la solidaridad de las gentes y de las ONGs para superar, no sólo las desigualdades, sino también las injusticias. Pero, ¿es posible la solidaridad en las sociedades avanzadas?, ¿sirve para algo?. Trataremos de demostrar que la solidaridad es el marco que puede posibilitar la superación de las injusticias, que la solidaridad siempre ha tenido lugar en la sociedad, aunque bajo formas que esconden cierto cálculo o acción calculada, y que las ONGs han de fomentar una cultura civil solidaria a través de la participación y la responsabilidad civil como expresión de libertad.

Si desde la solidaridad, la amistad, la benevolencia, beneficencia, fraternidad, hemos evolucionado hacia la justicia, ahora nos retrotraemos para superar lo que no ha conseguido la justicia. Sin embargo, sigue siendo la justicia el objetivo fundamental por cumplir, mientras consideramos como complementaria la solidaridad. ¿Por qué no profundizar entonces en la justicia?. Porque no acaba con las diferencias sociales, ni se acerca, al igual que otros sistemas, a los problemas más acuciantes que padecen los ciudadanos. De momento, nadie puede denunciar ante los tribunales a la sociedad por no tener trabajo, falta de vivienda, y escasos medios por ser inmigrante o padecer la soledad, el sida, sin ser atendido adecuadamente.

44 Cfr. Colectivo Ioé, (1992), La Inmigración Extranjera en Catalunya. Balance perspectivas. Institut Català d'Estudis Mediterranis. Generalitat de Catalunya, Barcelona. 
La solidaridad nos saca de nosotros mismos, abriéndonos a un contexto que supera la subjetividad. Con la solidaridad se supera lo local, lo que Nagel en ética llama superación de la subjetividad moral, por la conexión con otras condiciones subjetivas de otras latitudes. Ese nuevo contexto, más amplio, es la llamada materialidad contextual e incluso transcontextual.

Adentrarse voluntariamente en nuevos y más amplios contextos, son modos de profundizar en la democracia por la participación. Es un modo de predisponer a los ciudadanos para que surja la solidaridad, a pesar de las ineludibles diferencias. Por lo tanto, cabe la solidaridad cuando se parte de la igualdad, a pesar de comprobar, al mismo tiempo, las diferencias. Precisamente por ello, la expresión solidaria es una manifestación de cálculo que supone un cange, un intercambio, y gracias al cual se mantiene entre los seres humanos esa igualdad básica, que es lo que nos procura la dignidad. Con lo dicho, no estamos hablando de un esencialismo solidario del ser humano, sino más bien de un aprovechamiento solidario de las diferencias, siempre y cuando se está dispuesto a compartirlas, y hacerse la vida más agradable. Se produce un cálculo solidario, aunque con una predisposición o mentalidad, que exige de los individuos ser conscientes de que dicho cálculo es más bien salir de uno mismo para vivir mejor en contacto con los demás. No se trata de un cálculo financiero o mercantil. Se trata de medir los pasos y dirigirlos según nuestras propias carencias, con la predisposición de entenderse, de alcanzar la universalidad del entendimiento. ¿Qué puede suceder si no lo hacemos así?. A la vista están las actuaciones independientes, dogmáticas, exclusivistas y sus consecuencias en el campo ecológico o medioambiental, económico y de convivencia social.

Ahora bien, ¿son las ONGs las encargadas de realizar esta labor o han de ser las redes primarias de solidaridad quienes la practiquen de verdad?. La misma complejidad social exige una apertura del individuo a instancias intermedias (ONGs), que han de tener sumo cuidado en mimar la espontaneidades de las que se nutren (redes primarias). Son los ámbitos de la llamada sociedad civil, en los que se combina la tradición acumulada con la eficacia, flexibilidad y proyección de futuro, donde cabe la participación directa y el respeto, al mismo tiempo, por las funciones que desempeñan los diversos miembros, según la responsabilidad asumida en el diseño de los programas o de la acción social programada. Sin embargo, también caben desviaciones, interconexiones, acuerdos y alianzas para alcanzar objetivos, que, sin olvidar el de la solidaridad, pueden combinarse para lograr mejor imagen institucional, desarrollo de la ideología por la eficacia o poder crítico y de presión frente a las instituciones estatales. En cualquier caso, el individuo está en condiciones de asumir aquel nivel intermedio que 
más se acomode a sus cálculos de solidaridad, según las redes existentes o las que está dispuesto a crear como ejercicio de su libertad ${ }^{45}$.

Desde las ONGs se reduce la complejidad de los problemas sociales, debido a la flexibilidad y proximidad a los ciudadanos que los padecen. Pero también se exige el apoyo de ciertas condiciones infraestructurales, contextuales, para superar el individualismo y fomentar las virtudes políticas de que habla Rawls, o las virtudes públicas, entre ellas la solidaridad, de que habla Victoria Camps ${ }^{46}$. Esas condiciones las deben propiciar las políticas sociales activas, desde el Estado hasta las Autonomías y los poderes locales. En caso contrario, es difícil alcanzar lo que propone la citada autora para eliminar la droga: «Las medidas para eliminarla son diversas, desde la atención médica y recuperación de la drogodependencia a la despenalización de la droga, pasando por la persecución de sus agentes». Más bien ocurre lo contrario, y «no tiene sentido que un asistente social dé una jeringa a un toxicómano y un policía le detenga por usarla» ${ }^{47}$.

Las ONGs y los movimientos sociales que apuntan a la acción social, asumen las cuotas de responsabilidad civil correspondientes cuando colaboran extendiendo la conciencia solidaria capaz de modificar actitudes, roles discriminatorios, penalizaciones de la diferencia y de la marginación ${ }^{48}$.

Como quiera que son posibles las desviaciones, las ONGs han de percatarse de que, como tales, no han de acotar los espacios para evitar intromisiones. Si superamos el individualismo y caemos en el institucionalismo, no avanzamos. La capacidad de integrar y de atender a gentes diversas con los programas, marcan los niveles de solidaridad que ejecutan las entidades que intervienen en la acción social. La mayoría de las ONGs apuntan a quienes más lo necesitan, a los descolgados del mercado.

Ahora bien, ¿hay suficiente bagaje histórico que nos dé esperanzas de que el ser humano puede ser solidario?. La solidaridad admite formas diversas y seguramente las seguirá produciendo a tenor de las cir-

45 Un ejemplo reciente lo tenemos en «Los vecinos de 200 ancianos les auxiliarán si tienen problemas». Heraldo de Aragón 16-6-93. Se refiere a la soledad o emergencias que padecen 200 ancianos de la ciudad de Zaragoza, y que serán atendidos mediante un sistema de alarma por los vecinos.

46 Cfr. Victoria Camps, (1990). Virtudes Públicas, Espasa-Mañana, Madrid. p.33-54.

47 Es la opinión que expresa Luc Montagner, investigador y descubridor del virus del sida. EL PAIS, 16 de junio de 1993.

48 Es la razón por la que las ONGs han sido excluidas del comité que negocia en Viena la redacción del documento final de la Conferencia Mundial de Derechos Humanos. Es un modo de levantar un muro entre la sociedad civil y los Estados, según han manifestado aquéllas. 
cunstancias y de los contextos ${ }^{49}$. Es poco probable que cambiando las circunstancias no cambien las formas de expresar la solidaridad. Serán formas diversas de plasmar la universal solidaridad, que parten del ser humano y su contexto. Hoy la competividad, el progreso, el equilibrio ecológico, la eficacia, la soledad, el paro, la inmigración o el sida, son algunas de las nuevas circunstancias que definen nuestra sociedad. No cabe por tanto hablar de solidaridad al margen de semejante realidad. Podrá hacerse un pacto contra el paro, no sólo por interés de los muchos que lo padecen, sino también para mantener el bienestar de los que trabajan. Limitar los desórdenes que procura el hombre en la naturaleza, no se plantean sólo para disfrutar de un mayor equilibrio con ella y que procura bienestar; también lo hacemos para sostener, aunque de modo más equilibrado, el progreso actual y futuro. Cuidar a un enfermo de sida, no sólo lo hacemos porque le asiste el derecho, sino también para que no se propague la enfermedad, aun cuando se sobrepasen los umbrales económicos destinados a ellos.

En semejantes circunstancias, la sociedad demuestra cierta solidaridad, al mismo tiempo que calcula los costes económicos, políticos y de cualquier otro orden. No por ello deja de existir la solidaridad. En todo caso, sería cuestión de desmitificarla, aclarando aquellas ocasiones que brinda la sociedad para desarrollar conductas solidarias a tenor de lo que ocurre hoy. No se trata ni de ser héroes, genios o santos, cosa poco probable en la actualidad. Se trata de entender que siendo solidarios aumentamos la comunicación, superamos la soledad, profundizamos en el conocimiento del ser humano, hacemos uso de la libertad y de la participación y responsabilidad social, tenemos nuevas experiencias, prolongamos el sentido de la utilidad social de nuestra persona, y hasta adquiere la vida cotidiana un sentido cambiante y motivado.

Caben múltiples ejemplos de solidaridad. Si fulano acaba sus horas de trabajo, sale después en bicicleta o juega al tenis, sale de copas o va al teatro, y dedica un par de horas, dos días a la semana, a las personas que atienden los Hermanos de la Cruz Blanca, es tan solidario como aquel otro que con semejante o diferente horario laboral, compagina trabajo, su afición por el fútbol o el baloncesto, con la dedicación de ocho horas mensuales, al APA del colegio o Instituto donde cursa su hijo/a, los estudios. Las diferencias pueden establecerse por la cantidạd (número de horas) y por la calidad (preparación específica) de las prestaciones solidarias. Sin necesidad de extendernos en ejemplos, las conductas solidarias se combinan de muy diverso modo con tareas o funciones que atienden distintas facetas del ser humano. No tiene por 
qué existir el sacrificio o la privación. Puede ocurrir lo contrario: que se haga de buen grado por la gratificación que procura la conducta solidaria, por la fuerza vital que produce acompañar y sentirse acompañado en una experiencia común, de mutua ayuda.

Más allá de los casos concretos, y a modo de síntesis histórica, encontramos planteamientos y muestras de solidaridad diferentes. Aquella solidaridad socrática que nos hace iguales en la comunidad por participar del Logos, por el diálogo entre iguales. Aquella otra solidaridad estoica, de élite, que hace autónomos entre sí a quienes la Razón Universal les ha dado sentido, «humanidad». La solidaridad cristiana de las comunidades perseguidas, mesiánicas, la que procura la comunión mística. La solidaridad de las comunidades que, por la prohibición del incesto, desarrollan el intercambio para sobrevivir mejor; o la de los jefes numaym que con la celebración de los potlaches ayudan a vivir a los más pobres a cambio de prestigio. La solidaridad totémica o solidaridad del grupo en el origen común. La solidaridad utópica de la isla de Tomás Moro, o la de Tomás Campanella en la Ciudad del Sol. La solidaridad como corresponsabilidad entre civiles y religiosos en Luis Vives. El pacto social de Rousseau, como expresión de solidaridad. La solidaridad Kantiana, universal, en base a la naturaleza común del ser humano. «La solidaridad de los modernos» en Adam Smith vinculada a la armonía que producirá la razón, la ciencia, la productividad y la economía. La solidaridad de Max Sheler basada en la reciprocidad y equivalencia. La solidaridad de Xavier Zubiri, formando parte del ser humano y aquella otra que tiene presente a los demás. La solidaridad a distancia con el Tercer Mundo, a través de una cuenta bancaria. La solidaridad sentida y expresada entre los turcos residentes en Alemania y los que habitan Turkía. O la solidaridad entre los negros africanos con los negros norteamericanos, por apaleamiento o asesinato de uno de estos últimos.

La solidaridad entre los hombres ha existido y existe. No cabe, por tanto, despreciarla porque adivinemos intereses, estrategias, cálculos lícitos y legítimos. Ahora bien, si hemos demostrado que ha existido y existe solidaridad, ¿las ONGs siguen en esa misma línea, son expresión sus programas de solidaridad activa puesta al día?. Ya hemos expresado que la complejidad de la sociedad y de los problemas que ésta presenta exigen de una organización compleja y al mismo tiempo flexible para plantear el tratamiento del sida, la inmigración, los malos tratos, o cualquier otro problema. En tales problemas, ¿Dónde existe el «cálculo de solidaridad» por parte de las ONGs?. Básicamente en que no hay ánimo de lucro. Los servicios prestados pueden llegar a ser totalmente gratuitos; se muestra ante la sociedad la transparencia necesaria, se presiona, si fuera menester, a los poderes locales; se divulga un estilo y una estructura teórico-técnica de enfocar los problemas que 
se tratan. A cambio se conecta con la sociedad y con los ciudadanos; se reciben ayudas económicas o prestaciones humanas voluntarias, esporádicas o sistemáticas; institucionalmente se consigue un respeto, una confianza y cierta admiración por la labor ejercida; se es fuente de experiencia y eficacia profesional, se constituye en orientadora de los problemas que trata, es garantía de mayor participación; trabajar o colaborar con la institución da prestigio profesional y humano; se convierte en referente social en campos socio-políticos; es también un poder fáctico a tener en cuenta, y difunde su pensamiento o ideología, caso de profesarla, indirectamente.

A lo expresado llamamos «cálculos de solidaridad» en el ámbito de las ONGs que actúan en la acción social y los servicios sociales. Estas demuestran que la solidaridad rebasa el peldaño de la subjetividad. No es cuestión de entenderla ni de practicarla desde la subjetividad plural; es cometido ahora de entidades e identidades complejas de mayor nivel y que simbolizan la integración con otras alternativas, y no sólo por el ámbito laboral convencional. La razón de semejante fenómeno lo explicábamos con anterioridad. No sólo existen problemas, diferencias, sino que son cada vez más dolorosas y más complejas, moviéndonos a la solidaridad ante el destino de nuestros semejantes y de nuestra especie. Claro, que uno se pregunta si es conveniente que las ONGs, entre otras entidades, se conviertan en mediadores múltiples de la sociedad civil. Queremos decir, que ejerzan de paradigmas de participación democrática, eficacia, presión política, ético-moral, tolerancia, integración y solidaridad.

No cabe duda de que la participación democrática formal es insuficiente. Por otra parte, y más en nuestro país, es un auténtico milagro diario la democracia de la que somos autores, y todo aquello que ha sido capaz de levantar y consolidar. A pesar de lo cual, los hay que se sienten desencantados de no haber alcanzado mayores cotas de progreso múltiple.

En la actualidad es un clamor social la exigencia de mayor participación en todo aquello que nos concierne como ciudadanos y como personas concretas. Los ciudadanos, por contra, apenas si asumen responsabilidades públicas voluntariamente, tal y como sucede en el ámbito privado ${ }^{50}$. Por eso mismo, pocos se creen que el ámbito público sea una garantía para conseguir bienestar o felicidad. El paro ha limitado drásticamente el número de quienes disfrutan de cierto nivel material; y la consecución de la felicidad la buscamos en maltrechas comunidades que basculan entre la modernidad y la tradición. ¿Dónde cabe

50 Cfr. Victoria Camps, (1993), Paradojas del individualismo, Edit. Drakontos Crítica, Barcelona. p.89-105. 
la integración con la existencia del paro y reducida la vida feliz a pura subjetividad? Si no hay modo de participar en la vida pública e integramos en ella, se nos pide la integración, y compran el silencio por aparentar haber alcanzado la felicidad en lo privado, sin trabajo y marginados. Curiosa, por lo demás, paradoja, que hace incompatibles integración y participación, vida pública y consecución de la felicidad, justicia y solidaridad.

Las ONGs como entidades intermedias se justifican ante el presente y el futuro, por ofrecer una combinación (institución-individuo) que hace todavía posible, por la práctica de la igualdad, la libertad y la solidaridad, una comunidad que actualiza la tradición, el pasado, con las exigencias de la sociedad moderna. Que establece un puente de unión entre la persona y la comunidad, por la práctica de la solidaridad. Que procura la comunicación entre el egoísmo individual (yo) y el egoísmo racional (nosotros) por la participación.

Las ONGs muestran un nuevo estilo de solidaridad porque la complejidad social lo impone. No se trata de presentar dualidades antagónicas: ONGs frente al Estado; público contra privado. Como el proceso no ha sido lineal, la reiterada complejidad hace posible que las entidades intermedias combinen la justicia con la solidaridad, la tradición con la modernidad, lo público con lo privado, la participación con la democracia, la felicidad con la presencia de los demás. Esto precisamente constituye el nuevo estilo.

El nuevo estilo no es que haya conseguido fabricar un espacio neutro y abstracto (el de las ONGs). En éstas se actúa, se decide, se orienta, existe el sentido de la orientación, se encarna en lo próximo, como diría MacIntyre. Se ha conseguido una complejidad operativa, solidaria y tolerante, concreta y con vocación universal o de entendimiento progresivo. Es un nuevo estilo ético que «acentúa la importancia de las esferas intermedias, las corporaciones o instituciones que vehiculan las tradiciones de las prácticas del bien -que cubren el espacio abierto entre el individuo y el Estado $\rightarrow{ }^{51}$.

Es un nuevo estilo que conforma la nueva cultura de la solidaridad, por la vía de la participación y no de la imposición racional mayoritaria. Del contexto que se va gestando surge la nueva responsabilidad civil, que une el pasado con el presente, lo general con lo particular, al individuo con la identidad comunitaria. Sería lo que algunos llaman la nueva religiosidad.

Las ONGs no es que representen una reducción de la universal solidaridad. Lo que sí demuestran es una manera de progresar hacia ella,

5l Carlos Thiebaut, (1992), Los límites de la comunidad, Edit. Centro de Estudios Constitucionales. Madrid. p.38-39. 
partiendo de las exigencias complejas, y en parte descritas, de nuestra sociedad moderna. No deben caer, por tanto, en el particularismo de sus intereses institucionales, ya mencionados, o en la acotación del espacio social con «sus» voluntarios, «sus» programas, «su» eficacia intransigente e impositiva, «su» denuncia y «su» palmarés de éxitos locales o internacionales.

Las ONGs, como expresión de solidaridad y superadoras de sus intereses institucionales, habrán de constituirse en espacios de libertad civil y participación, mayores que los que ofrece el Estado a nivel sectorial, territorial o en el Consejo Económico y Social. Es una forma más de solidaridad: hacer partícipes a los ciudadanos de sus destinos, de aquellas actividades que les afectan en la vida personal y pública y sin ánimo de control ${ }^{52}$. Es un modo de lograr parte de la realización personal a través de la cooperación con otros, en entidades cuyos miembros se conocen y hacen en ella expresión de su libertad. En entidades mayores, la representatividad, el profesionalismo, el anonimato y la falta de participación impiden la realización personal y limitan las libertades.

El Informe sobre desarrollo humano 1993, elaborado por el Programa de las Naciones Unidas para el Desarrollo (PNUD), admite entre sus conclusiones que «Sólo uno de cada diez personas en el mundo puede participar plenamente en la actividad política, económica, social y cultural que influye en su vida, pese a los cambios en favor de las economías de mercado y la democracia registrados en los últimos años» ${ }^{53}$. En los países en desarrollo la gente del campo disfruta de la mitad de los servicios sociales de que disfrutan los de la ciudad. También se calculan en 1.000 millones las personas que viven en la pobreza. Con esto queremos decir que la seguridad del bienestar alcanzado hasta ahora en los países industrializados peligra y la solidaridad calculada puede ser más comprensible y necesaria que nunca, mientras no cambien las cosas. ¿Mundo industrializado y solidaridad calculada frente a los excluidos y marginados?. Intentamos ser realistas y aproximar la utopía, todo lo más posible, a las circunstancias del momento. Por eso hablamos del interés y la motivación que debe existir en el mundo occidental frente al «peligro», cada vez más creciente de los más pobres, los niños, las mujeres, las minorías y los grupos indígenas, los habitantes de las zonas rurales, los discapacitados (el 10\% de la población mundial). 
El mismo hecho de que las ONGs se conviertan en ámbito de plena participación activa es todo un reto para extenderla a otras esferas, como la política, la economía o el conjunto social. Las ONGs tienen en sus manos la posibilidad de concienciar a los ciudadanos de la necesidad de participar, de ser más libres por la participación, de elegir la solidaridad como fórmula de cooperación entre iguales a pesar de mantener sus diferencias. No de otra forma se han promovido cuestiones como las de la mujer, los derechos humanos y el equilibrio ecológico. Esta es precisamente la paradoja que nos puede hacer avanzar: romper la homogeneización, claramente manifiesta en el modo de expresarse, vestirse, admitiendo que la pluralidad, la complejidad, además de ser un hecho, es un reto, y las ONGs están bien situadas para afrontarlo. Dichas entidades son la tabla de salvación para tantas diferencias, marginales en la acción social, prontas a desaparecer por su identidad cultural entre los pueblos indígenas, sospechosas de la economía sumergida o alternativa para poder sobrevivir, de profundización democrática por el asociacionismo o cualquier otra fórmula de participación libre y no convencional.

5. Es imprevisible el futuro papel que van a jugar en la sociedad las ONGs, la redes de solidaridad primaria, la solidaridad expresada en sus diversos niveles.

Sin embargo, en los apartados anteriores hemos tratado de ir exponiendo el camino seguido por las ONGs y la solidaridad históricoconceptual, para llegar a un punto sin retorno. Ese punto sin retorno es el contexto que nos toca vivir, y quien nos dicta que la trayectoria seguida no es lineal; que los antagonismos y dualidades se superan en la complejidad presente, y punto sin retorno que nos ha dado a conocer los errores cometidos.

Así las cosas, y matizando todo lo que sea necesario sobre los conceptos de integración, solidaridad, participación, democracia, eficacia, comunidad, igualdad, libertad, justicia y felicidad, es como podemos llegar a un diagnóstico aproximativo de lo que ha constituido el llamado Estado de Bienestar y el papel que las ONGs pueden desempeñar en el que está por venir. Así es como llegaremos a saber quién o quiénes, y de qué manera pueden seguir esperanzados en aunar combinando las diversas variables, para hacer posible un rebajado Estado de Bienestar para todos, cuando se habla poner límites al Estado; aquellos límites de la acción del Estado, de que hablara ya Wilhem von Humboldt ${ }^{54}$.

En el punto anterior hemos intentado explicar que se han producido las circunstancias para avanzar hacia una solidaridad, aunque sea cal-

54 Cfr. Wilhem von Humboldt, (1988). Los límites de la acción del Estado. Estudio preliminar y notas de Joaquín Abellán. Ed. Tecnos. Madrid. 
culada, no tan universal como quisiéramos, pero tan real como la que se produce en el contexto presente. Y ello a pesar de las pocas posibilidades que nos da E. Miret Magdalena de ser solidarios con un ideal. El mismo, y a pesar de las frases tópico citadas del profesor Eloy Luis André (1910), de Salvador de Madariaga y de Menéndez Pidal, reconoce como una «paradoja típicamente española», cosa que ocurre en cualquier país de Europa, que «los hispanos estamos dispuestos a ayudar a una persona concreta, cuando está a nuestro lado, y compartir con ella nuestro pan $»^{55}$. «Una sólida mayoría (64\%) está dispuesta a sacrificarlo todo por alguna persona y sólo un $27 \%$ se resisten a ver una causa por la que se pueda sacrificarlo todo» ${ }^{56}$.

Una solidaridad, que a tono con la complejidad alcanzada por la sociedad, la muestran también las ONGs, pudiendo ser no sólo una demostración actualizada de la misma, sino una fórmula más amplia de convivencia y participación futuras. No resta ahora sino ensayar aquellas directrices que harían posible en el futuro la superación de los niveles de complejidad alcanzados en el presente. Intentamos decir que la universalidad de la solidaridad se puede alcanzar con la adecuación a los contextos, cada vez más complejos. Y ese camino ha de recorrerse, hoy por hoy, con la presencia más activa de las ONGs desde el punto de vista estructural. Seguramente que, para entonces, habrán surgido escalones intermedios, imprescindibles y necesarios para subir los siguientes.

Nos inclinamos por pensar que dicha solidaridad ha de partir desde abajo, desde lo próximo a nosotros. Es lo que más nos afecta. Después ha de venir el abrirse al «nosotros» cada vez más amplio. Pero hemos de partir de lo vecinal y local. Si después alcanzamos la universalidad, que parece demandar el ideal de la solidaridad, habremos progresado. Pero tampoco hemos de obsesionarnos con los universales cuando no hemos aprendido todavía a aceptar positivamente las diferencias.

Partimos intuitivamente, para desarrollar con fundamento la solidaridad, de la necesidad de buscar o reparar, sin más, las similitudes que nos aproximan y que nos hacen iguales sin ningún tipo de imposición. Así es como la solidaridad puede surgir por un proceso más natural que aquel otro impositivo. Nosotros hemos entendido que, aunque tal proceso encierre un cierto cálculo, es bastante más provechoso, por el intercambio producido entre iguales, que aquel otro que se derive de normas impuestas por la sociedad. Es Rorty quien nos comenta que «los sentimientos de solidaridad dependen de las similitudes y las di-

s6 Amando de Miguel, (1992) La sociedad española 1992-93. Alianza Editorial. p.466. 
ferencias que nos causen la impresión las más notorias, y tal condición de notorio es función de un léxico último históricamente contingente».

Contingencia y léxico que no esconden substrato o esencia humana sobre la que tengamos que fundamentar una obligada moral universal. Lo que más nos puede aproximar, dice Rorty, en medio de la gran heterogeneidad es «el dolor y la humillación». Y, ¿dónde se encuentra semejante banco de pruebas?. La sociedad nos da todo lujo de detalles en cuanto a marginación y sufrimiento se refiere. Ya lo hemos comentado: desde el paro hasta la enfermedad del sida, pasando por los malos tratos, drogadicción e inmigración, disponemos de un abundante muestrario para aplicar y comprobar la validez de la tesis del filósofo norteamericano Richard Rorty.

A partir de la aceptación de la posible universalización de la solidaridad, pero pisando tierra y arrancando desde la autoayuda y la ayuda próxima, podemos proseguir tolerantemente hacia fórmulas cada vez más compartidas, aunque sean todavía frágiles. Sin obsesionarse por el éxito a largo plazo hemos de trabajar con lo inmediato y a corto plazo, sin fomentar falsas esperanzas, pero tampoco plegándose a la impositiva fragilidad, de la que sólo es posible escapar, según otros, por la trascendencia.

Quienes están más próximos a las redes primarias de solidaridad son las ONGs. Estas últimas son un escalón superior si nos referimos a la organización y disposición de medios técnicos y humanos. Sin embargo, la espontaneidad, la cantera de la solidaridad y de la responsabilidad civil, se encuentra en la familia, entre los vecinos, amigos, conocidos, voluntarios ocasionales, personas que las hace coincidir la actividad laboral o aquellas otras tan variadas que pueden abarcar desde lo lúdico-deportivo y cultural hasta lo religioso.

Por ser las ONGs las más próximas a las redes de solidaridad señaladas, habrán de fomentarlas, apoyarlas técnicamente y conocerlas al máximo para saber, en la medida de lo posible, aquellas fórmulas nuevas y precisas que se necesitan incentivar ante los problemas sociales detectados, y aun antes de que afloren a la superficie de la sociedad.

Las ONGs son las entidades encargadas de enlazar y presionar ante las élites y el gran grupo con los marginados y pobres. El enlace es necesario porque constituye, de por sí, una desincrustación de la responsabilidad civil en expansión. Cuando no sucede así es cuando la gente opina que los problemas van a seguir, e incluso van a crecer, y que la responsabilidad de la marginación la tienen los propios sujetos que la padecen. Una gran mayoría opina así ante fenómenos sociales como la homosexualidad, alcoholismo, suicidios, prostitución y drogadicción.

El modo más operativo de la conducta solidaria lo pueden ejercer, entre otros, las ONGs. A estas entidades les corresponde, por propia 
responsabilidad, la labor de organizarse y programar conjuntamente aquellos programas que con más urgencia se necesitan poner en práctica y que ya se han planteado.

Aunque el futuro nos sorprenderá en cuanto a las acciones concretas, se han de orientar desde parámetros claramente planteados. Por ello, en el posible modo de actuar conjunto de las ONGs hemos de distinguir dos niveles conectados: el preventivo y a largo plazo, y el puntual y a corto plazo. Con el primero se pretendería encauzar y alertar a los ciudadanos de los peligros que nos acechan por no modificar determinados hábitos de conducta social; y con el segundo se actuaría puntual, técnica y coordinadamente.

Lo que se dice de modo tan rápido se hace más complejo cuando, en el nivel preventivo, buscamos el método y aquellas expresiones e imágenes puntuales que han de oír los ciudadanos a través de los medios de comunicación sobre los problemas de droga, sida, inmigrantes, racismo, malos tratos o personas mayores. En definitiva, cuesta trabajo encontrar un lenguaje que apunte a ser común, por haber alcanzado el compromiso, y que abra al máximo las posibilidades y medios legales de colaboración y entendimiento con los poderes públicos, hasta ahora máximos responsables ${ }^{57}$.

Aunque no es nuestro propósito llegar a los detalles, pensamos que en el futuro las ONGs habrán de comunicarse para actuar en programas conjuntos con división detallada y específica de funciones. Se exigirá por tanto una especialidad, una mayor complejidad en las estructuras técnicas que afrontan los problemas sociales. La división de funciones no es obstáculo para englobar, por ejemplo, técnicos con voluntarios. La misma responsabilidad civil hará entender que determinados cometidos no se pueden desempeñar en las ONGs con la mera aportación de la voluntad. Es la razón de la necesaria formación, la preparación, el ensayo, la experiencia, la supervisión. Se trata de un equilibrio entre la participación solidaria y la técnica de la intervención, que se verá ajustada por la investigación participativa de los procesos, de los programas desarrollados. Y no habrá de ser, por tanto, evaluación exclusiva de técnicos o de voluntarios, de la administración o de los agentes directos de la intervención.

La colaboración entre las ONGs es una demostración de solidaridad, cuando se trabaje en programas conjuntos, campañas conjuntas, se construya un lenguaje común, como común sea el fondo económico con que se financien algunas de las actuaciones, se intercambien las metodologías y las experiencias técnico-profesionales.

57 Se han de poner al día los mecanismos legales favorecedores de la colaboración con los entes públicos, cuando se trata de gestionar e intervenir socialmente en cualesquiera de los programas puntuales (Inmigrantes, sida, personas mayores, droga). 
Para afrontar los problemas hemos de partir de la constitución de grupos muy reducidos (3 ó 4 técnicos) para asesorar directamente a la red o infraestructura creada de servicios, y que estarán poniendo en práctica, al mismo tiempo, diversos programas, con el apoyo de los citados grupos técnicos ${ }^{58}$.

La coordinación de los grupos técnicos se realizaría desde unidades centralizadas, capaces de favorecer el desarrollo de las funciones prefijadas de todos los componentes en ćada uno de los programas.

Queremos añadir, para acabar, que el cumplimiento escrupuloso de las funciones y responsabilidades que se asumen en los programas no ha de ser obstáculo para que, periódicamente, todos aquéllos que intervienen, sin excepción, conozcan el proceso en su conjunto, y tengan ocasión de opinar sobre cualquier aspecto del mismo, sin que por eso se desdibujen las estructuras prefijadas. Es la manera de que la participación responsable se cumpla, más allá de aquellos cometidos que cada uno asume.

Con la actuación técnico-puntual y la visión de conjunto de los problemas, rebasamos ese nivel tan peligroso que es el localismo de las meras necesidades. Las necesidades sociales suelen estar interconectadas además de explicitar problemas mayores, problemas colectivos y estructurales.

La coordinación entre las ONGs y los programas que desarrollen nos dará luz, más allá de lo que haga cada una de ellas y de su zona de actuación, para comprender a través de los informes, que la visión de conjunto es la que demuestra la complejidad de los problemas sociales, siendo necesarios planteamientos de actuación conjuntos y complejos.

Con la participación en los programas, tanto de técnicos como de «profanos», el lenguaje se depura de tecnicismos y es puente de comunicación con la problación, directamente o a través de los medios de comunicación. Es un modo de trasparentar las propias ONGs y su estructura, a la población para la que trabajan, sin aparentar poder institucional o técnico, no impidiendo que sea la misma gente quien haga oír su voz, y no necesariamente y siempre, a través de las ONGs.

$¿$ Que ocurre entonces con la anunciada solidaridad calculada de las ONGs?. Dicho de otro modo: ¿qué ganarían con todo este modo de actuar?. ¿Lo darían todo a cambio de nada?. Existe la rentabilidad so-

No debería constituir ningún obstáculo que las ONGs intervinieran en los programas desarrollados sobre la base de redes de servicios públicas. De esta manera los profesionales, y sobre todo los Trabajadores Sociales, dejarían de ser meros controladores del heterogéneo conjunto de marginados, y pondrían al día su metodología. Cfr. Fernando Alvarez-Uría, (1993) «La crisis del Trabajo Social» en Rev. Claves, n. ${ }^{\circ} 34$. p.49-53. 
cial, el buen nombre, la identificación por responsable, eficaz, serio y equilibrado. Es uno de los principios básicos que puede perseguir, en la convivencia entre iguales, cualquier persona, grupo u organización. Es el punto de partida de la cultura de la solidaridad, aquél que hace compatible la igualdad con la diferencia alcanzada por el esfuerzo, en aras del bien local y común. A partir de este principio, asumido por las ONGs, se puede ir construyendo un futuro que a buen seguro nos va a deparar grandes novedades. Dejaría de ser novedad, por no existir, la mutua desconfianza entre Administración y ONGs. 